\title{
Negative Polarity Items in Telugu
}

\author{
Mayuri J. DILIP
}

Indian Institute of Technology Madras, India

mayuri.dilip@gmail.com

\section{Rajesh KUMAR}

Indian Institute of Technology Madras, India

thisisrajkumar@gmail.com

\begin{abstract}
The paper presents a unified account of licensing conditions of Negative Polarity Items (NPI) in Telugu. Based on the distribution of NPIs in complex sentences that consist of embedded clauses, we state that negation c-commanding NPI is at the base-generated position. Consequently, features checking between negation and NPI restricts the alternatives on the scale inherent to NPIs. The morphological realization of NPI in the non-negative contexts is different from the context with overt negation. The NPIs show the following distribution. NPI occurs in subject position; A negative licensing Multiple NPIs. There are three types of NPIs: wh-element, quantifier and idiomatic expression. In complex sentences, wh-elements block long-distance licensing. In contrast, quantifiers and idiomatic expressions do not block long-distance licensing.
\end{abstract}

Keywords: Negative Polarity Item; minimalist-based approach; feature checking; quantifier scale; c-commanding

\section{Povzetek}

Članek predstavlja celovit pregled pridobitvenih pogojev (angl. licencing conditions), ki zadevajo k nikalnosti usmerjene izraze (Negative Polarity Items ali NPI) v teluščini. Na osnovi porazdelitve teh izrazov $v$ sestavljenih stavkih z vrinjenimi stavki zagovarjamo tezo, da se s-poveljevanje k nikalnosti usmerjenim izrazom izvede na položajih, ki izhajajo iz osnove. Posledično preverjanje značilnosti med nikalnostjo in $k$ njej usmerjenimi izrazi omejuje druge možnosti in sicer preko lestvice, ki je povezana z izrazi NPI. Morfološka realizacija takšnih izrazov v nenegativnih kontekstih je drugačna od kontekstov z očitno negacijo. K nikalnosti usmerjeni izrazi izkazujejo naslednjo porazdelitev. Pojavljajo se na položaju osebka kot negativno pogojeni večkratni izrazi NPI. Obstajajo trije tipi k nikalnosti usmerjenih izrazov: vprašalnice, števniki in 
idiomatični izrazi. V sestavljenih stavkih vprašalnice zaustavijo oddaljeno pridobivanje, medtem ko ga števniki in idiomatski izrazi ne.

Ključne besede: $k$ nikalnosti usmerjeni izrazi; minimalistični pristop; preverjanje značilnosti; lestvica števnikov; s-poveljevanje

\section{Introduction}

This paper discusses the syntactic description of Negative Polarity Items (NPI) in Telugu, a Dravidian language. An NPI usually requires a negative licensor as discussed in several studies such as Lasnik (1972), Linebarger (1980), and Laka (1989), Progovac (1994) among others. Some argue for overt licensing involving NPIs (Lasnik, 1972; Kumar, 2006) whereas others argue for licensing at some other level such as Logical Form (LF) (Line Barger, 1980; Laka, 1989; Mahajan, 1990; Progovac, 1994; Balusu et al., 2016). This paper aims at providing a unified account of licensing conditions of NPIs in Telugu, specifically wh-elements (wh-NPI), quantifiers (q-NPI) and idiomatic expressions (i-NPI), in negative \& non-negative contexts and in local \& long-distance licensing contexts by adopting Kumar's (2006) analysis which is further modified into a minimalist-based approach. In order to depict feature checking between negation and NPI, we adopt operation Agree (Chomsky, 2000) and scalar reasoning (Chierchia, 2013; Nicolae, 2012).

The organization of the paper is as follows: section 2 discusses the basic structure of negation and affirmation; section 3 discusses the structural distribution of wh-NPIs, q-NPIs and i-NPIs; NPI in subject position; the occurrence of multiple NPIs, the complement clauses exhibiting restriction on long-distance licensing of NPIs; NPIs in non-negative contexts; section 4 illustrates the quantificational structure of NPIs; section 5 describes licensing conditions of NPIs; section 6 is conclusion.

\section{Structural description of negation and affirmation}

The morphological and syntactic description of negation and affirmation is necessary, since they play a significant role in restricting the distribution of NPIs in Telugu. The discussion is elaborated below.

In Telugu, the morphological structure of sentential negation varies in verbal predicate with a content verb as in (1a) and a non-verbal predicate such as an existential verb as in (1b). In every construction including (1a) and (1b), the negation always precedes the agreement marker. Where the agreement marker also functions as a finiteness marker in Telugu. In the case of the verbal predicate as in (1a), the negative marker $l \bar{e}$ occurs as a bound morpheme suffixed to the main verb except in the case of the verb with future tense. In future tense, an overt form of negative marker is absent. Therefore, we assume that the negative marker occurs in the same position 
as in past and present tense and we indicate its presence with $\varnothing$ 'a zero morpheme'. There are various negative markers such as -vaddu, -kūdadu, -a-, -aka-, -akunḍā/-kunḍā, -aku-, le- and ani- (Krishnamurti \& Gwynn, 1985). These markers occur in different contexts and they follow the main verb similar to the marker -le. In the case of nonverbal predicate as in (1b), the negative occurs as a fusional morpheme, when the verb is in the present or the past tense. By fusional morpheme, we mean that the verb functions both as negation as well as copula. However, in future tense, it occurs as a bound morpheme suffixed to copula un- 'be'. In (1a) and (1b) the past tense and the present tense morphemes are homophonous. ${ }^{1}$

1a. rāmu rā-lē-du/ rā-lē-du/ rā- $\emptyset$-ḍu Ramu come-PRES.NEG-3.SG.N/come-PST.NEG-3.SG.N/come-FUT-NEG-3.SG.N 'Ramu does not come. / did not come. / will not come.'

1b. rāmu inți-lo lē-ḍ/ lē-ḍu/ unḍ-a-ḍu

Ramu house-LOC be.PRES.NEG-3.SG.M/be.PST.NEG-3.SG.M/be-FUT.NEG-3.SG.M 'Ramu is not at home./ was not at home./ will not be at home.'

Lahiri (1998), Kumar (2006) and Bhattacharya (2012) show that the element that occurs as an NPI also occurs in certain non-negative contexts. In section (3.5), (non-)negative contexts show that the morphological structure corresponding negative contexts never occur with a non-negative contexts. In contrast, the morphological structure corresponding non-negative contexts never occurs in a negative context. The point to be noted is that the variations correspond to the functional categories such as negation and affirmation. Therefore, the formal negation and affirmation play a role in determining the type of NPI. Before moving on to how the functional categories license NPIs, we describe the syntactic representation of negation and affirmation in a tree structure. In a syntactic representation, similar to the previous studies such as Pollock (1989), Chomsky (1991), Mahajan (1990), Kumar (2006), Laka (2016), the negative heads its own phrase called NegP and the NegP projects below TP and above AspP, located in the functional domain as in (2).

\footnotetext{
${ }^{1}$ The tense being past or present can be proved by positing the time adverb ninna 'yesterday' or ippudu 'now' in (1a) and (1b). In the presence of ninna 'yesterday', the verb exhibits past tense. In contrast, in ippudu 'now' occurs in (1b), then the verb indicates present tense.
}

i a. rāmu \{ninna/ippuḍu\} rā-lē-du

Ramu \{yesterday/now come-\{PST/PRES\}.NEG-3.SG.N

'Ramu did not come yesterday.'/'Ramu will not come now.'

ii b. rāmu \{ninna/ippuḍu\} inți-lo lē-ḍu

Ramu \{yesterday/now house-LOC be-\{PST/PRES\}.NEG-3.SG.M

'Ramu was not at home yesterday.'/'Ramu is not at home now.' 
2. Position of negation in a tree structure:

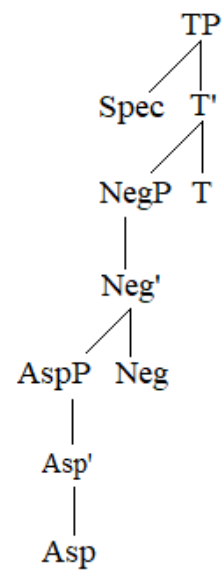

In the case of affirmation in the non-negative contexts, we adopt Laka's (2016) analysis, where the affirmation heads its own syntactic projection called an Affirmative Phrase (AffP) and it occurs in place of NegP. Morphologically, there is no overt marker for affirmation in Telugu, hence we posit a zero morpheme exactly in the same position where a negative morpheme occurs in a negative clause. Now, in the following section, we discuss the structural description of NPIs in Telugu by comparing it with English and Hindi.

\section{Structural description of NPIs}

In this section, we demonstrate the variations and restrictions of NPIs occurring in different types of clauses. The structural variations that we discuss in this section help us understand the licensing conditions of NPIs. We observe the structure of Telugu by comparing it with Hindi and English. Such comparison among languages belonging to three different language families helps us to identify the location of the licensing conditions in the clause structure.

\subsection{Description of three types of NPIs}

In line with Lahiri (1998), Kumar (2006) and Balusu et al. (2016) the NPIs are attached with a particle indicating 'even'. In Telugu, the particle is kūọa or the final vowel lengthening. The root of an NPI can be a wh-element, quantifier or an idiomatic expression similar to Hindi as in (3), (4) and (5). To the best of our knowledge, we do not find a wh-element and a quantifier as NPIs in English. However, English has idiomatic expression as in (5c).

3a. Telugu

rāmu evvarini-i $\quad$ avamāmāninc-a-lē-du/*avamāmāninc-ā-ḍu\} 
Ramu wh-even.NPI \{insult-PST-NEG-3.SG.N/insult-PST-3.SG.N\}

'Ramu did not insult anyone.'

3b. Hindi ${ }^{2}$

rāmu ne kisī kā bhī apmān \{nahĩi kiyā thā/ *kiyā thā\}

Ramu erg wh even-NPI insult \{not do PST.SG/ do PST.SG\}

'Ramu did not insult anyone.'

4a. Telugu

rāmu okkarini kūọ̄ā avamāninca-lē-du/avamāninc-ā-ḍu

Ramu one person even.NPI insult-NEG.PST-3.SG/ insult-PST-3.SG

'Ramu did not insult anyone.'

Literally: 'Ramu did not insult one person also'

4b. Hindi-Urdu

rāmu ne ēk vyakti ka bhī apmān nahi kiyā thā/ *kiya thā

Ramu erg one person gen even.NPI insult not do PST.SG/ do PST.SG

'Ramu did not insult anyone.'

Literally: 'Ramu did not insult one person also'

5a. Telugu

nēnu nī-ku cilli gavva kūọā $\quad$ iivv-a-nu/*ist-ā-nu

I you-to single penny even.NPI \{give-NEG.PST-3.SG/*give-PST-3.SG\}

'I will not give a single penny to you.'

5b. Hindi ${ }^{3}$

mẽ tum-kō ēk phūți kaurī $\quad$ \{nahĩ dū-ngā/ *dū-ngā

I you-dat one broken penny.NPI \{NEG give-FUT.1.SG.M/ give-FUT.1.SG.M

'I will not give you a red cent.'

5c. English

He did not save a single penny.

(Ladusaw, 1983, p. 382; as cited in Ramachandram, 1991, p. 13)

\subsection{Occurrence of NPI in subject position}

Below are the constructions exhibiting the NPI in subject position. Both in Telugu and Hindi, all the three types of NPIs can occur in subject position as in (6a) and (6b). In English, the NPI anyone cannot occur in subject position as in (6c), since it cannot be licensed by structurally lower negation (Chierchia, 2013, p. 62).

\footnotetext{
2 Personal communication with Dr. Devleena Chakravarty, Ph.D.

${ }^{3}$ Kumar (2006).
} 
6a. Telugu

ēmī/okkați kūọā/cilli gavva kūọā lē-du

wh-NPI/q-NPI/i-NPI

be.PRES.NEG-3.SG.NH

'There is nothing.'

6b. Hindi

kōi bhī/ ēk bhī/ èk phūți kaurī nahĩ hẽ

wh-NPI/q-NPI/i-NPI not be.PRES.SG

'There is nobody.' / 'Not even one person is there.'/

'Even a single penny is not there.'

6c. English

*Any student didn't respond well. (Chierchia, 2013, p. 62)

\subsection{Occurrence of Multiple NPIs}

Below are the constructions with multiple NPIs licensed by a single negative licensor. In English as in (7a), the negative not licenses the NPI such as anybody, anything; in Hindi as in (7b), the negative nahĩ licenses the NPIs kōi bhī 'anybody', kahī 'anywhere' and in Telugu as in (7c), the negative -lē licenses the NPIs evarū 'anyone', ekkadiki 'anywhere'. Note that i-NPI cannot occur as multiple NPIs.

7a. English

He didn't give anybody anything at any place at any time.

(Kuno \& Whitman, 2004, p. 225)

7b. Hindi

kōī bhī kahī nahĩ Gayā

who even.NPI somewhere.NPI not go-PST.3.SG.M

'Nobody went anywhere.'

7c. Telugu

evarū ekkadikī vell-a-lē-du

who.even.NPI anywhere.NPI go-PST-NEG-3.SG.N

'Nobody went anywhere.'

\subsection{Structural restrictions of NPIs in various complex sentences}

In this section, we discuss the distribution of NPIs occurring in three types of complex sentences: adjunct clauses, complex NPs and complement clauses. Based on the structural restrictions in complex sentences, we classify the q-NPIs and i-NPIs as nonstrict NPIs and wh-NPIs as strict NPIs. A strict NPI is the one which does not permit longdistance licensing and in contrast, non-strict NPI does. The data where a negation locally licenses NPI do not exhibit any particular variations. Therefore, we show the 
data with clause-mate negative licensing in the appendix $D$ for the sake of brevity. The restrictions relating to long-distance licensing are further elaborated below.

In (8) and (9), the NPI occurs in the embedded clause and the negation $-l \bar{e}$ - in the matrix clause depicting long-distance licensing. The constructions show ungrammaticality, since the adjunct clause and the complex NP function as syntactic islands. That is, the negation in the matrix clause cannot license the NPI in the embedded clause.

\section{NPIs in adjunct clauses}

8a. *rāmu ikkaḍiki [evari-kī cepp-i] rā-lē-du

Ramu here whom-with.evenNPI tell-CPM come-NEG-3.SG.NM

'*Having telling anyone, Ramu did not come here.'

8b. *rāmu [koncem kūọā tin-i] paḍu-ko-lē-du

Ramu little even.NPI eat-CPM sleep-SELFBEN-NEG-3.SG.NM

*'Having eaten little also, Ramu did not sleep.'

8c. *rāmu ikkaḍiki [cilli gavva unḍi] rā-lē-du

Ramu here single penny.NPI having come-NEG-3.SG.NM

*'Ramu did not come here with single penny.'

\section{NPIs in complex NPs}

9a. *[evvarū vāḍina] katti] nī daggara lè-du

who.even.NPI used knife you with be.NEG-3.SG.NM

*'The knife which is used by anyone is not with you.'

9b. *[koncem kūḍā panḍina panḍu] pullagā lē-du little even.NPI ripen fruit sour-adjl be.NEG-3.SG.NM

*'The fruit which ripened at all, is not sour.'

9c. *[cilli gavva kūọā unna] nī-ku] lāțarī tagala-le-du single penny even.NPI have you-DAT lottery get-PST.NEG-3.SG.NM

*'You who have a single penny, did not win a lottery.'

The complement clause as in (10a) shows that a wh-NPI evaru.u exhibiting longdistance licensing leads to ungrammaticality as in (10a). The ungrammaticality is because the embedded clause functions as a syntactic island blocking the long-distance licensing. In contrast, q-NPI konni-kūọā and i-NPI cilli gavva kūọā exhibit long-distance licensing as in (10a) and (10b). Due to the possibility of long-distance licensing, q-NPIs and i-NPIs are non-strict. 


\section{NPIs in complement clauses}

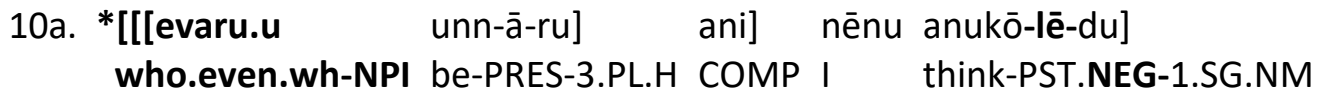

'I did not think that there is anybody.'

10b. [[[konni kūọā unț-ā-yi] ani] nēnu anukō-lē-du] few-even.q-NPI be-PRES-3.PL.H COMP I think-NEG.PST-3.SG.NM 'I did not think that there can be few also.'

10c. [[[nī daggara cilli gavva kūḍā un-țun-di] ani] anukō-lē-du] you with single penny even.i-NPI be-PRES-3.SG.NMCOMP think-NEG.PST -1.SG.NM 'I did not think that you will be having a single penny also.'

\subsection{Occurrence of an NPI in non-negative contexts}

The previous studies such as Lahiri (1998), Kumar (2006) and Bhattacharyya (2012) among others discuss the occurrence of NPIs in non-negative contexts such as yes/no question, conditional, imperative, generic, modal of possibility and adversative predicate. The data in the studies mentioned above shows that the morphological composition of NPI is identical in negative as well as in non-negative contexts as in (11) and (12). For example, the NPI in the presence of negation is any or kisii bhii as in (11) and the NPI in the non-negative context will also be any or kisii bhii as in (12) (for NPI in non-negative constructions in Hindi see Kumar (2006)). However, Telugu being morphologically rich language, NPIs in non-negative contexts as in (13)-(18) are morphologically different from the one in the presence of overt negation. That is, the NPI is attached with kūọa 'even' in the presence of a sentential negation and in contrast, NPI is attached with aina 'at least' in non-negative context. In the following section, we demonstrate the quantificational restrictions of NPI in non-negative context (NPI-aina hereafter) and the NPI in the presence of overt negation (NPI-kū also describe a correlation at the level of semantic configuration between both the types of NPIs.

\section{Hindi-Urdu}

maiN-ne kisii bhii sTuDeNT ko nahiiN dekh-aa I-ERG any.NPI student to NEG se-PERF 'I did not see any student.' (Kumar, 2006, p. 109)

12. Hindi-Urdu: Yes/No Question aap-ne kisii bhii sTuDeNT ko dekh-aa (kyaa) you-ERG some even student to see-PERF what 'Did you see any student?' (Kumar, 2006, p. 111) 
13. Telugu: Yes/No Question

ā rūm lo evar(u)-ainā unn-ā-r(u)-ā?

that room in who-at least be-PST-3.PL.H-INT

'Is anybody there in that room?'

14. Telugu: Conditional

okavēla ā gadilō-ki evarainā vaste, nēnu nī-ku cept-ā-nu

if that room-in who at least come, I you-to tell-PST-3.SG

'I will let you know, if anybody comes into the room.'

15. Telugu: Imperatives

èdainā tinu

which at least eat-3.SG

'Eat anything.'

16. Telugu: Generics

yē pilli ainā eluka-ni vēțāọu-tun-di

any cat at least rat-ACC hunt-GEN-3.SG.N

'Any cat hunts a rat.'

17. Telugu: Modals of Possibility

evvarainā ì tēbl ni etta-galugutā-ru

who at least this table ACC lift-poss-3.PL.H

'Anyone can lift this table.'

18. Telugu: Adversative Predicates

nuvvu ēdainā ceppāvanțe nā-ku āscaryangā un-di

you who.atleast tell I-DAT surprising be.PRES-3.SG.NM

'I am surprised that you told anything to the police.'

Summing up the discussion in this section, Telugu differs from English, where the NPI can occur in subject position in Telugu. In English, Hindi and Telugu, negation licenses multiple NPIs. The complement clauses in Telugu, wh-NPIs are strict NPIs since as they do not allow long-distance licensing. In contrast, q-NPIs \& i-NPIs function as non-strict NPIs since they allow long-distance licensing. The NPI in the negative context and in the non-negative contexts show morphological variations. In the following discussion, we claim that NPI-ainā and NPI-kuḍa are counterparts of a single type of NPI.

\section{Semantic description of NPIs: an alternative-based structure}

In this section, we discuss the quantificational restrictions of NPIs by adopting analyses of Chierchia (2013) for NPI-kuḍ̄ā and Nicolae (2012) for NPI-ainā. Chierchia's analysis of NPIs provides an answer to the question, "Why the class of NPI licensors is semantically uniform and why NPIs have the shape they do?" The analysis takes place 
through the process of feature checking, where the negation is the goal and the NPI is the probe. The probe inherently has a scale with active quantificational alternatives arranged over it, where the alternative to the right entails the alternative to the left. For example, if the scale is <one, two, three...>, two entails one. The scale functions as the uninterpretable feature of the probe, in other words [UNEG]. Negation which is the goal consists of negative features which function as the interpretable features such as the [iNEG]. In line with Lahiri's (1998) analysis of NPIs, the emphatic operator is associated with a low-point element in a scale and this point functions as semantically the strongest alternative. Strongest alternative, in the sense, it functions as threshold, where no other alternatives further entails it. For example, ék bhi 'any.NPI' as in (19) has èk, indicating the numeral 'one', which is a low-point on the active alternative scale. This low-point functions as a strongest alternative, in which case, anything that is entailed within $\bar{e} k$ are counted. Since the alternatives entailed in $\bar{e} k$ is zero alternatives, $\bar{e} k$ bhi in a negative context indicates 'no individuals'.

19. ēk bhī ādmī nahĩ āyā

any.NPI man not came

'No man came.' (Chierchia, 2013, p. 156)

This procedure of selecting the lowest point in the scale and making it semantically strongest is called scale truncation. In other words, the alternative that functions as a threshold is considered the least likely alternative and only those alternatives lesser than the threshold are active. The entire process mentioned above occurs only in downward-entailing context.

Nicolae (2012) provides an alternative-based semantic account of PPIs. The analysis lays a connection between a PPI and an NPI. In this analysis, the super-domain alternatives are active in a PPI. That is, the alternatives which entail the emphasized alternative are counted. For example, in the scale <one, two, three...> if we suppose that two is the emphasized alternative, any numeral entailing two is a super-domain. In other words, any numeral greater than or equal to two, which are $<t w o$, three... $>$ are considered to be a part of the super-domain. Such activation of super-domain occurs in upward-entailing context only. In contrast, the sub-domain alternatives are active in the case of NPI. For example, in the scale <one, two, three...> if two is the emphasized alternative, then the sub-domain would be anything that two entails. Hence, the subdomain includes one, since two entails one. We make a modification to Nicolae's analysis, where we apply the PPI's analysis to NPI-ainā. Further, we do not call NPI-ainā as PPI, since the context is semantically negative, even if it is morphologically/ syntactically affirmative.

The application of Chierchia (2013) and Nicolae (2012) to NPIs in Telugu has the following results. Recall that NPI-kū $q \bar{a}$ is a counter-part of NPI-ainā and the evidence is shown at the morphological level in constructions with non-negative context. We claim 
a similar correlation of NPI-kūḍa and NPI-ainā at semantic level as well. The discussion is elaborated below. The NPI-kūḍa and NPI-ainā possess an inherent neutral element and we label it as a Polarity Item (PI), which is identical to both NPI-kūdā and NPI-ainā. By identical, we mean that the PI has a quantificational scale with active alternatives arranged in a linear, incremental order, where the alternative on the right entails the alternative on the left and one among the alternatives is an emphatic alternative, where it functions as a threshold/mid-point. The quantification on the scale is restricted, consequent to the negation/affirmation influencing the PI. Note that the particle $k \bar{u} d \bar{a}$ or ainā realizes only following the feature checking depending on what type of restriction exists on the scale. In the case of an NPI-kūdōa, due to the influence of the overt negation, the sub-domain alternatives remain active and the super-domain alternatives are cancelled. In the case of NPI-aina, due to the influence of the overt affirmation, the super-domain alternatives are active and the sub-domain alternatives are cancelled. The NPI-kūḍa and NPI-ainā are related at semantic level also. That is, the structure of alternatives that we demonstrated for NPI-ainā, consistently occurs in all the non-negative contexts as in (15)-(18).

Summing up the discussion above, we illustrated the quantification structure of NPIs in Telugu based on the alternative-based semantic analysis by adopting Chierchia (2013) and Nicolae (2012). The NPIs inherently possess a neutral element which has a scale with active alternatives. Due to the influence of a negative or affirmative features, the neutral element undergoes cancellation of certain active alternatives depending on the type of NPI. Similar to the correlation at the morphological level, NPI-kūọa shows a correlation with NPI-ainā at their semantic level also, where the NPI-ainā consistently shows active super-domain alternatives in all the non-negative contexts. NPI-kūdā has active sub-domain alternatives, NPI-ainā has active super-domain alternatives. We discuss the feature checking of NPIs along with their licensing conditions in the following section.

\section{Licensing conditions of an NPI}

In this discussion, we demonstrate an analysis which is a combination of syntactic and semantic operations. We compare previous studies such as Mahajan (1990), Chomsky (1995), Kumar (2006) and we conclude that Kumar's analysis of c-commanding best suits NPIs in Telugu. In addition to Kumar's analysis, we adopt the Chomsky's (2000) feature checking similar to operation Agree and also Chierchia's quantificational restriction. The analysis is elaborated below.

Mahajan (1990) states that the negative licenses the NPI at the level of LF, where the negative moves to a position higher than the NPI, adjoining the finite IP so that the negative c-commands the NPI. Mahajan's analysis encompasses the fact that the 
negation c-commands the NPI. However, the analysis may not be suitable for Telugu, particularly for construction depicting long-distance licensing as shown in (20).

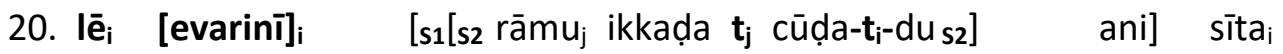
neg who even.NPI Ramu here see-NEG-3.SG.NM] comp Sita cepp-in-di s1] tell-PST-3.SG.NM]

'Sita said that Ramu did not see anyone here.'

In (20), the NPI and the negative base-generate within the embedded clause and the NPI is scrambled out of its position. Under Mahajan's analysis the negation moves and it adjoins the finite IP at LF in a way that the negative c-commands the NPI. However, the adoption of Mahajan's analysis has the following problems: a. there is no limit to the number of heads moving. $b$. The movement of the negation is long-distance i.e. it moves from the embedded clause to the left of the finite IP. Such movement is a violation of head-movement constraint. c. The negation cannot move above the adjoined NP, since the adjunction functions a barrier for movement. d. Before the movement, the negative only negates the embedded clause. However, after the movement of the negative, to form an adjunct of a finite IP, the negative negates the entire sentence, that is, the embedded and the matrix clause. As a result, it is a violation of the structure preserving principle, since there is a change in the scope at PF and LF.

Chomsky's (1995) reconstruction states that the NPI is reconstructed at a lower position, so that the negative c-commands the NPI. However, the analysis may not be suitable for analysing NPIs in Telugu.

21. Surface Structure

[[sītai tīsin-a yē fōṭō kūọā $]_{j} \quad$ tanaki nacc-alēdu ani] rāmu

Sita take-ADJL Photo even.NPI her like-not COMP Ramu cepp-ā-du $\quad t_{j}$

tell-PST-3.SG.M

'Ramu said that she does not like any photograph that Sita took.'

22. Logical Form

${ }^{*} e_{j}$ tanaki nacc-alēdu ani rāmu cepp-ā-ḍu [sīta tīsin-a

her like-not COMP Ramu tell-PST-3.SG.M Sita take-ADJL

yē fōțō kūọā $]_{j}$

Photo even.NPI

'Ramu said that she does not like any photograph that Sita took.'

In (21) and (22), we find that sita tissin-a fōțō 'the photograph which is taken by Sita' is scrambled to sentence initial position, in a way that sita, a referential expression ccommands tanaki 'to her', a pronoun. However, when the scrambled element is reconstructed at the level of LF, then tanaki wrongly c-commands sita. We consider it 'wrongly c-commanding' in (22), since sita, a referential expression is supposed to be 
free everywhere. Further, not all NPIs occur in a scrambled position. This method of reconstruction may not be applicable for NPIs which are not scrambled.

Kumar's (2006) analysis of Hindi can be applied to NPIs in Telugu, since the problems that arose due to the application of the analyses mentioned above, do not arise in this analysis. Further, the analysis is suitable to account for strict NPIs, nonstrict NPIs, multiple NPIs and NPI in subject position in Telugu and Hindi as discussed in sections 3. Kumar's analysis states that the negative licenses the NPI at Deep Structure prior to movement at Surface Structure. Since the structure of Telugu is similar to Hindi, we adopt the analysis to account for NPIs in Telugu, where the negative licenses the NPIs at the base-generated position itself. Hence, even if the NPIs move out of their positions for achieving further operations such as Case and Agreement, they do not lose the negativity of the NPIs.

In order to license an NPI, the negative c-commands an NPI-kūọ $\bar{a}$ and an affirmative c-commands a NPI-ainā. Hoeksema (2000) provides evidence that more than c-commanding, it is the scope of negation and negative operators that license an NPI. However, we claim that the negative obligatorily c-commands the NPI at the level of LF. In order to prove our claim, we first illustrate how the strategy of c-commanding operates, when the NPI is the subject of a clause with a local negative licensor. Further, an illustration of an ungrammatical construction is provided, where the NPI occurs outside the c-commanding domain of the negative at the level of LF. The illustration is elaborated with the help of complex sentences below.

The construction in (23) has a structure depicted in (24), where the negative ccommands the NPI, prior movement to subject position. The operations do not lead to ungrammaticality.

23. [akkaḍa okkaḍu kūọā lē-ḍu] ani anukunn-ā-nu there one person even.NPI NEG-3.SG.M COMP think-PST-1.SG 'I thought that there is nobody.'

24. Structure of example 23:

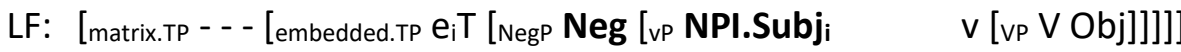
c-commanding

PF: [matrix.TP - - $\left[\right.$ embedded.TP NPI.Subj ${ }_{i}$ T [NegP Neg [vP $t_{i} v\left[{ }_{v P} V\right.$ Obj]]]]] no c-commanding

Now, we demonstrate how the occurrence of an NPI outside the c-commanding domain of negation at the level of LF leads to ungrammaticality. The construction in (25) has a structure depicted in (26), where the negative does not c-command the NPI, both at LF and PF. If we compare the LF in (24) and the LF in (26), we notice that the ccommanding strategy exists in (23) which is the structure of a grammatical sentence. 
Based on the correspondence between grammaticality and c-commanding in (23), we claim that the strategy of c-commanding is a necessary condition for the sentence to be grammatical. We further state that c-commanding also exists in licensing an NPIainā, where an affirmative licenses it, at the base-generated positions prior to movement for further operations.

25. *[akkaḍa lē-ḍu] ani okkaḍu kūọā anukunn-ā-nu. there NEG-3.SG.M COMP anyone.NPI think-PST-1.SG 'I thought that there is nobody.'

26. Structure of example 25:

LF:

[matrix.TP $\mathrm{e}_{i}$ T [vp NPI.Subji [vp V [embedded.TP - - - [Negp Neg [vp - - - ]]]]]]

PF:

I

no c-commanding

[matrix.TPNPI.Subj ${ }_{i}$ T [vp V [embedded.TP - - - [NegP Neg [vP - - -]]]]]]

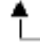

no c-commanding

However, c-commanding is not the only condition that is required to license NPI. If we adopt c-commanding as the only condition, the negation wrongly licenses every element that occurs in the c-commanding domain. In addition to c-commanding, the NPIs must have two more properties inherently such as, an active alternative scale and ainā 'epistemic at least'. These two properties play a role in feature interaction with their respective licensors. Feature checking takes place between negation \& NPI-kūḍa and affirmation \& NPI-ainā. Prior to the feature checking the NPI remains a neutral item as discussed in section 4. Below, we provide the feature composition that leads to the realization of different types of NPIs. In the configuration mentioned below, the properties on the left hand side together form either NPI-kūọ $\bar{a}$ or the NPI-ainā mentioned on the right hand side. The licensor identifies that an element is a NPI, by checking the active alternative scale inherent to the NPI. Further, the NPI takes the morphological realization based on the function of the particle, which is inherently present in it. A schematic representation of feature checking is provided in (27).

27. Before: [Negp Neg ${ }_{[i N e g]}\left[\right.$ [vP NPI.Subj ${ }_{[u-N e g]} v$ [vp V NPI.Obj $\left.\left.{ }_{[u-N e g]}\right]\right]$

After: [Negp Neg ${ }_{[i N e g]}\left[v p\right.$ NPI.Subj ${ }_{[u-N e g]} v$ [vP V NPI.Obj[u-Neg]]]]

In the case of NPI-kūḍa, the PI with the scale and the feature of emphatic 'even', checks its uninterpretable features with its goal, which has interpretable negative features, resulting in NPI-kūọa as in (a). In the case of NPI-ainā, the PI with the scale and feature of epistemic at least, checks its uninterpretable features with its goal, which has interpretable affirmative features as in (b). 
a. $\mathrm{PI}+$ negation + scale + inclusiveness feature $\rightarrow$ sub-domain alternatives of the threshold are active $\rightarrow \mathrm{NPI}-k \bar{u} d \underline{a}$.

b. $\mathrm{PI}+$ affirmation + scale + epistemic feature $\rightarrow$ super-domain alternatives greater than or equals to the threshold are active $\rightarrow$ PPI-aina .

Summing up the discussion in this section, adopting Kumar (2006), we state that the negative/affirmative licenses the NPI vP-internally at the level of LF. Consequent to their occurrence in a c-commanding domain of the licensor, the polarity-sensitive items undergo feature checking, where the negative/affirmative function as the goal and the $\mathrm{NPI}$ as the probe. The probe is a neutral item with uninterpretable features such as the active alternative scale, along with one of the functions such as epistemic at least, dubitative or emphatic properties. Further, a goal is either an affirmative licensor or a negative licensor. In the process of feature checking, the probe checks its uninterpretable features with the interpretable features of the corresponding goal. As a result, the PI which is a neutral item morphologically realizes into NPI-kūọa or NPIainā.

\section{Conclusion}

In this paper, we described in detail, the distribution of NPIs followed by the analysis of licensing conditions. The distribution of NPIs covers the following. There are three types of elements that occur as the root of the NPIs: wh-elements (wh-NPI), quantifiers (q-NPI) and idiomatic expressions (i-NPI). When these elements occur in complement clauses, wh-NPIs function as strict NPIs, since they disallow long-distance licensing. In contrast, q-NPIs and i-NPIs function as non-strict NPIs, since they allow long-distance licensing. The NPIs occur in subject position, unlike English. Further, multiple NPIs can occur in a single clause. We notice that the NPI in the non-negative contexts possess a morphological structure different from the NPI in the presence of overt negation. It is $\mathrm{NPI}$-ainā in the non-negative contexts which is the counterpart of NPI-kūọa in the negative contexts. The evidence for such correlation between NPI-ainā and NPI-kūda $\bar{a}$ is based on the consistent occurrence of ainā 'at least' attached to the NPI in every non-negative construction. Further, a similar kind of consistency is noticed at the semantic level, where NPI-ainā in every non-negative context depict activation of super-domain alternatives. Based on the distribution of the NPIs mentioned above, we illustrated that the negative/affirmative licenses NPI-kūḍ/aina, when the NPI basegenerate at VP-internal positions at LF, prior any type of movement for Case/Agreement. Parallel to c-commanding, the polarity-sensitive items undergo feature checking. The negation/affirmation is the goal with negative/affirmative interpretable features. The polarity-sensitive item prior to feature checking is a neutral item (PI), a probe, which has uninterpretable features: active alternative scale and one of the functions such as emphatic even or epistemic at least. This scale is the main 
feature that distinguishes the polarity-sensitive item from other element in the ccommanding domain. It is the function of the particle, inherently located within the polarity item, which is also responsible for the type of NPI. In feature checking, the probe checks its uninterpretable features with the interpretable features of the goal, as a result, the NPI is realized into NPI-kūọā or NPI-ainā.

\section{References}

Balusu, R., Gurujegan M., \& Rajamathangi S. (April 5 - 8 2016). Bagel Problem Items in Telugu and Tamil. [Presention]. GLOW 2016 - 39 $9^{\text {th }}$ Generative Linguistics in the Old World. Georg-AugustUniversitat Gottingen.

Bhattacharyya, A. (2012). Polarity sensitive Any in Bengali. Master's thesis. Retrieved from http://triceratops.brynmawr.edu/dspace/handle/10066/10701.

Chierchia, G. (2013). Logic in grammar: Polarity, free choice, and intervention. OUP Oxford.

Chomsky, N. (1991). Some Notes on the Economy of Derivation and Representation. In R. Freidin (Ed.), Principles and Parameters in Comparative Grammar (pp. 417-454). Cambridge: MIT Press.

Chomsky, N. (1995). The minimalist program. Cambridge. MA: MIT press.

Chomsky, N. (2000). Minimalist inquiries: The framework. In R. Martin, D. Michaels \& J. Uriagereka (Eds.), Step by Step: Minimalist Essays in Honour of Howard Lasnik (pp. 89-155). Cambridge: MIT Press.

Gajewski, J. (2007). Neg-raising and polarity. Linguistics and Philosophy, 30(3), 289-328.

Hoeksema, J. (2000). Negative polarity items: Triggering, scope and c-command. Negation and Polarity, 115-146.

Krishnamurti, B., \& Gwynn, J. P. L. (1985). A grammar of modern Telugu. Oxford University Press.

Kumar, R. (2006). Negation and licensing of negative polarity items in Hindi syntax. Taylor \& Francis.

Kuno, S., \& Whitman, J. (2004). Licensing of multiple negative polarity items. In S. Kuno, Y.-K. KimRenaud \& J. Whitman (2004). Studies in Korean syntax and semantics (pp. 207-228). Seoul: International Circle of Korean Linguistics.

Ladusaw, W. (1979). Polarity sensitivity as inherent scope relations. Unpublished PhD thesis, University of Texas at Austin, Austin.

Ladusaw, W. A. (1983). Logical form and conditions on grammaticality. Linguistics and Philosophy, 6(3), 373-392.

Lahiri, U. (1998). Focus and negative polarity in Hindi. Natural Language Semantics, 6(1), 57-123.

Laka, I. (1989). Constraints on sentence negation. In I. Laka \& A. K. Mahajan (Eds.) Functional heads and clause structure (pp. 199-216). Cambridge: MIT Press.

Laka, I. (2016). On Syntax of Negation. Routledge.

Lasnik, H. (1972). Analysis of negation in English. (Unpublished doctoral dissertation), MIT.

Lee, Y. S., \& Horn, L. (1994). Any as indefinite plus Even. Manuscript. New Haven: Yale University.

Linebarger, M. C. (1980). The grammar of negative polarity. (Unpublished doctoral dissertation). MIT.

Mahajan, A. K. (1990). LF conditions on negative polarity item licensing. Lingua, 80, 333-348. 
Nicolae, A. (2012). Positive Polarity Items: an alternative-based account. In Proceedings of Sinn und Bedeutung. Vol. 12.

Pollock, J. Y. (1989). Verb movement Universal Grammar and the structure of IP. Linguistic Inquiry, 20, 365-424.

Progovac, L. (1991). Polarity in Serbo-Croatian: Anaphoric NPIs and pronominal PPIs. Linguistic inquiry, 22(3), 567-572.

Progovac, L. (1994). Negative and positive polarity: A binding approach. Cambridge: Cambridge University Press.

Ramachandran, S. (1991). Negativity in Tamil: Untying the undefinable not. University of Ottawa.

Zwarts, F. (1998). Three types of polarity. In E. H. F. Hamm (Ed.), Plural quantification (pp. 177-238). Dordrecht: Kluwer.

\section{APPENDIX A}

\section{A list of quantifiers}

The following list shows quantifiers attached with particle indicating 'even'. The nonoccurrence of a particle with the quantifier is depicted with ${ }^{* \prime}$.

Table A1: Universal Quantifiers

\begin{tabular}{ll}
\hline Telugu & Gloss \\
\hline andaru-u; *andaru-kuḍā/*antamandi.i; & that many people even [+human] \\
antamandi-kuḍā & \\
$\begin{array}{l}\text { anni.i/anni-kuḍā } \\
\text { *anta.a/anta-kuḍā }\end{array}$ & that many even [-animate][+countable'] \\
\hline
\end{tabular}

Table A2: Existential quantifiers

\begin{tabular}{ll}
\hline Telugu & Gloss \\
\hline *kondaru.u; kondaru & few people even [+human] \\
kudāākontamandi.i; kontamandi kuḍā & \\
$\begin{array}{l}\text { konni.i/konni kuḍā } \\
\text { *koncemu.u; koncem kuḍā/*konta.a; } \\
\text { konta kuḍaā }\end{array}$ & $\begin{array}{l}\text { few things even [-animate][+countable'] } \\
\text { little even [-animate][-countable'] }\end{array}$ \\
\hline
\end{tabular}




\section{APPENDIX B}

\section{A list of numerals}

The following list shows numerals attached with particle indicating 'even'. The nonoccurrence of a particle with the quantifier is depicted with '*'.

Table B1: Cardinal numerals with [+human] feature

\begin{tabular}{ll}
\hline Telugu & Gloss \\
\hline okkaḍu.u; okkaḍu kuḍā & one person even \\
iddaru.u; iddaru kuḍa & two persons even \\
\hline
\end{tabular}

Table B2: Cardinal numerals with [-human] feature

\begin{tabular}{ll}
\hline Telugu & Gloss \\
\hline okații.i; okați kuḍā & one even \\
renḍu.u; renḍu kuḍā & two even \\
\hline
\end{tabular}

Table B3: Ordinal numerals

\begin{tabular}{ll}
\hline Telugu & Gloss \\
\hline modațidi.i/ modațidi kuḍā & first one even \\
renḍavadi.i/ renḍavadi kuḍā & second one even \\
\hline
\end{tabular}

\section{APPENDIX C}

\section{A lists of wh-entities}

The following list shows wh-elements attached with particle indicating 'even'. The nonoccurrence of a particle with the quantifier is depicted with ${ }^{~} *$ '.

Table C1: wh-entities

\begin{tabular}{ll}
\hline Telugu & Gloss \\
\hline enduku.u; enduku kuḍā/dēniki.i; & why even \\
dēnikikuḍā & what even \\
èmi.i; *ēmi kuḍā & where even \\
ekkaḍa.a; ekkaḍa kuḍā & when even \\
eppuḍu.u; eppuḍu kuḍā & how even \\
*ela.a; *elā kūọā & who even \\
evaru.u; *evaru kūḍā & which ones even \\
èvi.i/ *ēvi kuḍāa & which one even \\
èdi.i/ èdi kuḍāa & \\
\hline
\end{tabular}




\section{APPENDIX D}

The negation licenses the NPIs locally. All the three types of NPIs can be licensed by a local negative licensor. The NPIs do not show any particular variations in the structure when they are locally licensed. NPIs depicting long distance licensing in similar type of complex sentences show variations in the licensing conditions which is elaborated in section (3.4).

1. NPIs in adjunct clauses

i a. rāmu ikkaḍiki [evari-kī cepp-akunḍā] vacc-ā-ḍu Ramu here anybody-with.NPI tell-without.Neg come-PST-3.SG.M 'Ramu came here without telling anyone.'

i b. rāmu [koncem kūọā tin-akunḍā] paḍu-konn-ā-ḍu

Ramu little even.NPI eat-without.Neg sleep-selfben-PST-3.SG.M

'Ramu slept without eating anything.'

i c. rāmu ikkaḍiki [cilli gavva lēkunḍā] vacc-ā-ḍu

Ramu here single penny.NPI without.Neg come-PST-3.SG.M

'Ramu came here without a single penny.'

2. NPIs in Complex NP

ii a. [evvarū vāọ-ani] katti] nī daggara un-di anybody.NPI use-neg knife you with be-3.SG.NM 'The knife which is not used by anyone, is with you.'

ii b. [koncem kūọā panḍ-ani panḍu] pullagā un-di little even.NPI ripe-neg fruit sour-adjl be-3.SG.NM 'The fruit which did not ripen little bit also, is sour.'

ii c. [cilli gavva kūọā leni] nī-ku] lāțarī tagil-in-di single penny even.NPI not have you-dat lottery get/win-PST-3.SG.NM 'You who do not have even a single penny, won a lottery.'

3. NPIs in complement clauses
iii a. [[[evarū
lē-ru]
ani] nēnu anu-konn-ā-nu]
anybody.NPI be.PRES.NEG-3.PL.h comp I think-selfben-PST-1.SG
'I thought that there is nobody.'

iii b. [[[konni-kūḍā lē-vu]

ani] nēnu anu-konn-ā-nu]

few-even.NPI be.PRES.NEG-3.PL.NH comp I think-selfben-PST-1.SG

'I thought that there cannot be few also.'
iii c. [[[nī daggara cilli gavva kūọā lē-du] ani] you with single penny even.NPI be.NEG.PRES-3.PL.NH comp anu-konn-ā-nu] think-selfben-PST-1.SG
'I thought that you don't have a single penny also.'




\section{Abbreviations}

\begin{tabular}{|c|c|}
\hline 1 & : first person \\
\hline 3/iii & : third person \\
\hline ACC & : accusative \\
\hline ADJL & : adjectivaliser \\
\hline COMP & : complementizer \\
\hline CPM & : conjunctive participle marker \\
\hline DAT & : dative \\
\hline DUB & : dubitative \\
\hline EMPH & : emphatic \\
\hline ERG & : ergative \\
\hline $\mathrm{F}$ & : feminine \\
\hline FUT & : future \\
\hline GEN & : genitive \\
\hline $\mathrm{H}$ & : human \\
\hline INDEF & : indefinite \\
\hline INF & : infinitive \\
\hline LOC & : locative \\
\hline M & : masculine \\
\hline $\mathrm{N}$ & : neuter \\
\hline NEG & : negative \\
\hline $\mathrm{NH}$ & : non-human \\
\hline NM & : non-masculine \\
\hline PERF & : perfective \\
\hline PL & : plural \\
\hline PRES & : present \\
\hline PST & : past \\
\hline QP & : quotative particle \\
\hline SELFBEN & : self-benefactive \\
\hline SG & : singular \\
\hline
\end{tabular}

